\title{
DIGITAL EXCLUSION DESPITE DIGITAL ACCESSIBILITY: EVIDENCE FROM AN ENGLISH CITY
}

\begin{abstract}
Digital exclusion This study provides a high resolution investigation of the socioeconomic determinants of digital exclusion or lack of engagement within a single and densely populated city - Portsmouth in the UK. It employs data drawn from a representative interview survey of 1,005 households from across the city in 2007. Multivariate statistical analysis identifies those significant factors raising or depressing the probability of being categorised as digitally excluded including, inter alia, age, gender, income, education, disability, tenure, working status, city neighbourhood districts ('supergroups') and the presence of young people in the household.
\end{abstract}

Key words: digital exclusion, internet access, U.K.

\section{INTRODUCTION}

Having internet access has many advantages for its users but excludes non users from its benefits. This has led to the use of the term 'the digital divide' which distinguishes the gap between information haves and have-nots (Hargittai, 2003, Norris, 2001). It has been argued that this divide is not just a clear distinction between the information haves and the information have-nots (Foley 2004, Warschauer, 2004) but also relates to the speed and level of access that is available to individuals to access online (Longley et al 2009 and Warschauer 2004). Other studies prefer to use the term 'digital unengagement' to the less comprehensive and arguably more judgmental term digital exclusion (Longley et al 2009). However, both terms represent the failure to engage significant proportions of the population in the use of internet technologies. The purpose of this study is to investigate the socioeconomic characteristics of those who are digitally excluded in the City of Portsmouth, UK.

Clearly, internet activity has many benefits for its users such as social networking, on-line shopping, on-line banking, paying utility bills, finding new and better employment opportunities etc. In today's labour market many jobs are advertised online and employers use the services of online recruitment sites to advertise these positions. Undoubtedly, not being engaged has a negative impact for those involved as this can lead to vulnerable groups in society being disadvantaged. Furthermore, concern has been expressed that lack of access to digital technologies could increase existing inequalities among individuals, and among socioeconomic groups within society (see Jackson et al 2003). This can exacerbate the severity of the more widespread problem of social exclusion.

To help reduce the problem of digital exclusion in the UK, the UK government in 2009 appointed Martha Lane Fox as the UK Digital Champion who launched the Digital Inclusion Taskforce.

Access to internet technologies among the British population has been quickly growing over the past decade as internet technology has become more pervasive in society. In 2011, $77 \%$ 
of Great Britain households had internet access. This is up from $61 \%$ in 2007, the year of our study (ONS, 2012), making the insights still relevant with regards to the attributes of the digitally excluded. Additionally, the number of households that were able to access the internet in 2007 varied across the country. The South West and London had high access selevels of $69 \%$ while the South East had access levels at 65\%. Yorkshire and the Humber, the North East and Northern Ireland each had the lowest access levels of 52\%, (ONS, 2009).

Internet access is not the principal issue of concern with regards to being digitally unengaged. Previous research has found that a lack of internet and general computer skills are the most important reasons for being digitally unengaged (see Dutton and Helpser, 2007). Those who lack these skills tend to be the unemployed and the retired. Recent studies show that $34 \%$ of retired and $48 \%$ of unemployed people use the internet (Dutton et al 2009). It cannot be denied that digital exclusion or at the very least a lack of digital engagement remains as these studies highlight the considerable number of citizens who do not seem to reap the harvests of the benefits that the internet can offer. Parayil (2005) suggests that "the digital divide is often portrayed in crassly reductive terms as a mere technological access problem that can be ostensibly address by providing cheap computing and communication technologies to the poor' [p. 41]. However, it is not just that these citizens may lack the resources needed but also the skills and confidence that are needed to engage with the technology. Those who are excluded are increasingly disadvantaged in their access to information, particularly as 'digital by default' initiatives develop as the basic framework for the supply of many public services.

The UK government addressed the problem of digital exclusion by setting up the UK Online Centres in 1999. Initially the purpose of the UK Online Centres was to give individuals public access to computers. Today, these centres are encouraging individuals to get online, offering them support to gain the skills and confidence that is required to use the internet. The UK Online Centres consists of 3,800 centre partners and 500 access points across the UK. These may be found in libraries, community centres, housing associations as well as in pubs and cafes. Individuals that uses this service across the UK, one third have no formal qualifications, more than $50 \%$ are in receipt of state benefit, $25 \%$ earn less than $£ 10,000$ per annum, more than 7 in 10 users are socially excluded while $29 \%$ of these individuals are unemployed and 33\% are retired On the Island of Portsmouth there are ten UK Online Centres that offer a variety of computer and internet courses to individuals of all ages that are either free or of low cost. Additionally, there are ten access points on the island that offers computer and internet access that may be free or of low cost (for more information visit www. www.ukonlinecentres.com).

In 2009, the UK government appointed Martha Lane Fox the Champion for Digital Inclusion and in 2010 was appointed as the UK Digital Champion. This role involved "...encouraging as many people as possible to go online, and improving the convenience and efficiency of public services by driving online delivery" (www.cabinetoffice.co.uk).

Simple logistic regression is used in this study to help understand the socioeconomic determinants of those that are digitally excluded or unengaged. The contribution of this paper is to identify the quantitative impact of the variables gender, age, income, education, disability, tenure, working status, city neighbourhood districts ('supergroups') and the presence of young people in the household which are key socio-economic and demographic factors that are expected to have some bearing on the phenomenon. In particular this study 
offers a detailed picture of digital exclusion and within a single urban location and offering policy makers some insights at an intra-urban level of the scope for closing the digital divide close to the ground.

This paper is organised in the following manner. The next section provides a review of the salient literature on digital exclusion and disengagement. The following sections describe, the City of Portsmouth, the data used, an outline of the modelling approach deployed and discusses the results. Concluding remarks are offered in the final section.

\section{DIGITAL EXCLUSION AND DISENGAGEMENT: A BRIEF RETROSPECT}

The term digital divide is a term that is used widely to describe those who have access to the internet and those who don't. The OECD (2001) claims the "term digital divide refers to the gap between individuals, households, businesses and geographic areas at different socioeconomic levels with regards both to their opportunities to access information and communication technologies (ICTs) and to their use of the internet for a wide variety of activities" [p.5]. Other studies differentiate between those without access as ex-users and non-users. Ex-users are those who used the internet but no longer do so and non-users have never used the internet (Dutton and Helsper, 2007). These users have different reasons for not using the internet. They report that "for non-users a lack of skills is a more important reason to not use the internet than for ex-users" whereas for "ex-users the most prevalent reason to stop using the internet is related to lack of interest or perceived usefulness" [p.14]. There are also a variety of reasons across different social groups for not using the internet. For the unemployed non-users cost is the more likely reason for not using the internet whereas for 'retired non-users especially feel that the internet is not designed to meet their needs' (Dutton and Helpser, 2007 p.14).

The disparity of internet use can also be observed across countries. This has been characterised as the 'global digital divide'. Ono and Zavodny (2007) investigates I.T. access and use in five countries, the US, Sweden, Japan, South Korea and Singapore using the variables gender, age, education and income. They concluded that differences prevail across all five countries in IT use but are more obvious in the three Asian nations than in the US and Sweden. There are also differences in the high income industrialised countries such as those of the EU-15. Vicente and Lopez (2006) focused on the patterns of ICT diffusion across the European Union. Their paper concentrated on the socioeconomic factors that help understand the digital divide with respect to the internet, computers and mobile telephony. They found that those who earn high levels of income, have higher education levels and students are more likely to use the internet than the unemployed, women and those older than 24 years. Vicente and Lopez (2006) also investigated the use of the internet by taking the country of residence into consideration. They concluded that France, Greece, Italy, Portugal and Spain are below the EU average whereas Denmark, Germany, the Netherlands, Sweden and the United Kingdom are above the EU average. Some studies have focused on the spatial differences that may exist within a country. In the US Warf (2012) found that internet access varied across the states such that New England, the Northeastern Seaboard and the Pacific Coast have high rates of connectivity while the Southern region experiences lower rates of connectivity.

At a country level there is further evidence of a digital divide. Social or economic barriers to access provide the basis of digital exclusion in the UK. Dutton et al (2009) using descriptive statistics found that the non-users are those with disability, lower incomes, lower 
socioeconomic status and has less schooling. Age is also an important factor on the digital choices that people make. However, it was reported that retired users did not differ from the employed in accessing health information. This accounted for $70 \%$ of retired users which increased since 2007. Dutton et al (2009) states "that the availability of health information on the Internet had become more widely recognised by elders" [p.20]. In an earlier report Dutton and Helsper (2007) claimed that "men, students, higher educated and higher income individuals are all more likely to use the internet than women, retired, disabled, lower educated and lower income individuals"[p.4]. Another national survey that focused on the quality of access to and use of the internet among 9-19 year olds in the UK found that inequalities by age, gender and socioeconomic status exists (Livingstone and Helsper, 2007). In a similar fashion in other countries a digital divide exists. Bucy (2000) found that income, education, age and family structure are important characteristics of those with on-line access while single mothers, members of lower socioeconomic groups and older people are the lowest with regards to internet use. More recent studies in the US found that older people, those with lower levels of education and lower income are still the prevalent differences that exist with regards to internet use (Warf, 2012). Racial differences are also a dimension of the US digital divide. This relates substantially to the racial differences found in education, income and occupation (Warf, 2012, Fairlie, 2004).

Other studies have investigated if any gender differences exist in using the internet. Ono and Zavodny (2003) investigated this for the period 1997 - 2001 using US data. They found that women were not as likely to use the Internet as men at all in the mid - 1990s. However, this gender gap seemed to have disappeared by 2000. They also found "...that women remained less frequent and less intense users of the Internet" [p.112]. However, Bimber (2000) reports a gender gap with regards to both internet access and use. "The access gap is not the product of gender-specific factors but is explained by socioeconomic and other differences between men and women. The use gap is the result of both socioeconomic and some combination of underlying gender-specific phenomena" [p.868]. More recent studies reinforce the findings that the gender gap has disappeared (Warf, 2012) and suggests that young women especially the more educated and who work in clerical jobs that such skills are necessary. In the UK evidence suggests that a gender gap exists but it has been decreasing over time. In 2009, $71 \%$ of men used the internet while $68 \%$ of women used the internet. However, in 2003 these figures for men and women were 64\% and 55\%, respectively (Dutton et al 2009).

From these studies it is evident that it is the most vulnerable people in society that are digitally excluded. This may increase the severity of the more widespread problem of social exclusion. This provides a link between social exclusion and digital exclusion. Winchester (2009) refers to social exclusion as "...the different ways in which some groups are persistently prevented from participating fully in society" [p.8]. Although, digital exclusion is not the cause of social exclusion it may leave those who are already excluded further behind as internet use is used increasingly by the rest of society. Digital exclusion is a modern factor that has the potential to reinforce social exclusion. There are huge concerns that these people who are excluded will be left behind as they will not be able to exploit the benefits that the internet offers. FreshMinds (2008) states, "...digital equality matters because it can help mitigate some of the deep social inequalities derived from low incomes, poor health, limited skills or disabilities" [p.5]. Having access to and using the internet can help the most vulnerable people in society. It can be used as a social networking tool to help vulnerable people who may find it difficult to form relationships socially (McKenna and Bargh 2000). It can also help those who are unemployed as many jobs are solely advertised online. Winchester (2009) states "those without basic ICT skills suffer a severe disadvantage or are in essence, excluded from large segments of the labour market". Dutton et al (2009) 
report $48 \%$ of the unemployed use the internet. This has only changed slightly since the 2003 report where $42 \%$ of the unemployed used the internet. For the elderly it may also help them feel less vulnerable, lonely and independent. Other studies such as Longley et al (2009) found that in the UK a lack of digital engagement has an association with material deprivation. However, this is not always the case due to factors such as lack of confidence, skills or motivation. 


\section{THE CITY OF PORTSMOUTH CONTEXT}

Portsmouth is the only island city in the UK. Portsea Island, upon which Portsmouth is situated, is extremely flat and low lying. Portsmouth has an urban population of approximately 200,000 residents living on a land area of approximately 40 square kilometres making it the most densely populated city in the UK outside of London (Portsmouth City Council 2012a). The City of Portsmouth is located on the south coast of England situated 64 miles south west of London and 19 miles south east of Southampton (see figure 1).

Figure 2 provides a more detailed map of Portsmouth showing each of the postcode districts. Observations based on a document ${ }^{\mathrm{i}}$ produced by Portsmouth City Council, in this section provide a useful insight as to where different groups of people reside in each of these postcodes. Portsmouth City Council (2010) uses the Output Area Classification (OAC) which is a very useful way of profiling the population of Portsmouth geographically. This information is based on the 2001 census. It must be taken into account that recent changes may affect the accuracy of this data but OAC "is regarded as robust and does not need to be updated as frequently as postcode or household level data" (Portsmouth City Council, 2010, p.7). Using the OAC there are 6 supergroups that relate to Portsmouth. These include blue collar communities, city living, prospering suburbs, constrained by circumstances, typical traits and multicultural. $49.2 \%$ of Portsmouth population fall into the supergroup typical traits, $16.31 \%$ fall into constrained by circumstances, $15.5 \%$ fall into city living, $8.12 \%$ fall into blue collar communities and multicultural while $5.88 \%$ fall into prospering suburbs (Portsmouth City Council, 2010).

PO6 is a rather mixed area as it includes some blue collar communities as well as areas that are constrained by circumstances. Paulsgrove and Cosham wards are some of the most deprived wards in Portsmouth (Portsmouth City Council, 2012b, p.10). PO6 also includes some prospering suburbs where residents are more likely to live in detached houses rather than flats and terraced housing or rent from the public or private sector. Households are also less likely to have no central heating and may have access to two or more cars. $40 \%$ of the population residing in Drayton and Farlington are wealthy achievers. "Wealthy achievers are some of the most successful and affluent people in the UK. Middle aged or older people predominate with many 'empty nesters' and wealthy retired" (Portsmouth Local Strategic Partnership, 2011 p.1). PO6 also includes areas with some typical traits. Typical traits include settled households, least divergent households, aspiring households as well as young families in terraced homes. PO6 also has a low black minority ethnic group (BME).

PO1 is the highly urbanised city centre area. The largest supergroup in PO1 is constrained by circumstances. Residents in these areas are more likely to live in flats and rent from the council and housing association rather than live in detached housing. Households are less likely to have access to two or more cars and residents are less likely to hold higher education qualifications. PO1 also includes Charles Dickens which is one of the most deprived wards in Portsmouth. "...Charles Dickens has the highest number of deprived small areas for income, employment, health, crime and education, skills and training" (Portsmouth City Council, 2012b, p.10). Multicultural is another supergroup of PO1. Residents in these areas are more likely to have been born outside the UK and are from Black and Asian ethnicities. Residents are more likely to live in flats and rent from both the private and public sector rather than detached housing. Other supergroups include city living, some blue collar communities and typical traits. 
The largest supergroup for PO5 is city living. Residents in these areas are more likely to live in flats and rent from the private sector rather than detached housing. Residents are also more likely to hold higher level qualifications, live alone but are not pensioners. Households are also below the national average with non-dependent children and 5-14 year olds. Other supergroups for PO5 include typical traits, multicultural and areas constrained by circumstances.

The largest supergroup for PO3 is typical traits. Residents in these areas are more likely to live in terraced houses are unlikely to rent from the council and housing association. Other supergroups that are within the PO3 postcode include prospering suburbs, areas constrained by circumstances and some blue collar communities

PO4 and PO2 are mix of all supergroups but typical traits are popular for both. However, PO2 have more output areas that are constrained by circumstances than PO4.

The data and analysis considered in the following sections shed light on the extent of digital exclusion amongst Portsmouth residents'. The modelling conducted explores the characteristics of these residents who report they are digitally excluded but also sheds light on the spatial patterns of digital exclusion in the City of Portsmouth. 


\section{DATA}

The data used in this study is obtained from a resident's survey carried out by Portsmouth City Council in 2007. The survey was conducted by Ipsos Mori and commissioned by Portsmouth City Council and the survey sampled covered 1094 households. Approximately, $92 \%$ of the households contacted responded to this survey leaving a sample size of 1,005. Respondents were interviewed face-to-face in their own homes between 6 October and 14 December 2007. Respondents were randomly selected from sampling points across the city, using a stratified sampling method based on the 2001 census (gender, age and work status). Only households within the Portsmouth boundary where the respondent was aged 16 or over were included. An issue with the survey is that one third of the sample did not reveal their gross household income. For these missing observations an income variable was imputed using multiple imputations. ${ }^{\text {ii }}$

Table 1 and Table 2 provides a cross tabulation of those who are digitally excluded by each of the explanatory variables. Table 1 statistics for income uses the imputed income variable whereas Table 2 excludes those who did not reveal their gross household income for all variables. As expected the strength of the cross tabulations is improved as the imputed income variable provides more observations. Figures 2-5 uses data from Table 1.

This paper considers the determinants of digital exclusion. Digitally included means that the respondents have access to the internet at home either by broadband via a high speed, always - on connection (e.g. via ASDL or cable modem) or internet at home via a 'dial up modem' or internet at work, place of study or elsewhere. From the survey, approximately $64 \%$ of the respondents are digitally included. Table 1 shows that females are slightly more digitally excluded than males, $39.1 \%$ of females are digitally excluded while $32.6 \%$ of males. Digital exclusion is also considered by age. Figure 3 shows there is a large distinction between age groups. There is a consistent increase in digital exclusion by age. It ranges from $14.5 \%$ to $86.4 \%$. There is a large increase between the age group 45-54 and 55-64. For the age group, $45-54,24.2 \%$ are digitally excluded and for age group 55-64, 53.2\% are digitally excluded. This shows a significant increase of 29 percentage points between these age groups. It clearly shows that over 55 s are more digitally excluded.

Digital exclusion can also be considered by education. There is a distinction between the different levels of education as respondents who do not have a degree or GCE (General Certificate of Education) A level have a significant proportion that are digitally excluded (see figure 4).

Figure 5 shows that income levels are also related to digital exclusion. Respondents who earn at the higher level of income of $£ 600+$ are very much digitally included. The respondents who fall into the lower income categories have a larger proportion of those that are digitally excluded except those who earn under $£ 50$ per week only $20 \%$ of those respondents are digitally excluded. This may relate to students who are working while studying.

Respondents who are retired, unemployed or homemakers have the highest proportions that are digitally excluded. Additionally, respondents who rent from the council or housing association have a larger percentage of respondents that are digitally excluded, $63.9 \%$.

Digital exclusion can be considered by the presence of young people (under 18) in the household. Households that have no young people, $43.5 \%$ of these respondents are digitally excluded while households that have young people in the household only $24.8 \%$ of these 
respondents are digitally excluded. Respondents who report having a disability which limits their daily activities of the work they can do $74 \%$ of this group are digitally excluded.

Figure 2 shows that Portsmouth is divided into six postal areas PO1-PO6. It also shows the percentage of respondents that are digitally excluded by each of the postcodes. Residents who reside in postcode PO1 and PO6 have the highest proportion of respondents that are digitally excluded $48.8 \%$ and $44.4 \%$, respectively. This is followed by PO5, PO2, PO3 and PO4. 
Table 1: Cross Tabulation of those who are digitally excluded in Portsmouth, England by each of the explanatory variables

\begin{tabular}{|c|c|c|c|}
\hline $\begin{array}{l}\text { Explanatory } \\
\text { Variables }\end{array}$ & Definition & $\begin{array}{l}\text { Number of } \\
\text { Respondents } \\
(\mathrm{N}=1,005)\end{array}$ & $\begin{array}{l}\text { Digitally } \\
\text { Excluded (\%) }\end{array}$ \\
\hline Gender & $\begin{array}{l}\text { Gender of individual } \\
1=\text { male } \\
0=\text { female }\end{array}$ & $\begin{array}{l}473 \\
532\end{array}$ & $\begin{array}{l}32.6 \\
39.1\end{array}$ \\
\hline Age & 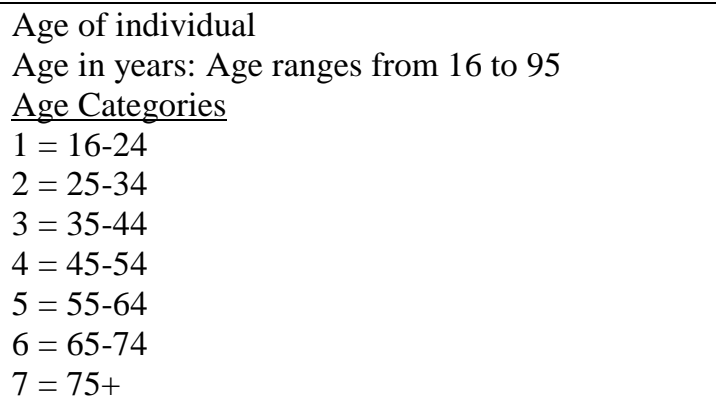 & $\begin{array}{l}166 \\
158 \\
213 \\
132 \\
126 \\
107 \\
103\end{array}$ & $\begin{array}{l}14.5 \\
19.0 \\
20.7 \\
24.2 \\
53.2 \\
71.0 \\
86.4\end{array}$ \\
\hline $\begin{array}{l}\text { Highest Educational } \\
\text { Qualification }\end{array}$ & $\begin{array}{l}\text { What is your highest educational qualification? } \\
1=\text { Degree or equivalent } \\
2=\text { GCE A Level or equivalent } \\
3=\text { GCSE grades A, B, C or equivalent } \\
4=\text { GCSE grades D, E or equivalent } \\
5=\text { Other } \\
6=\text { None of the qualifications } \\
7=\text { No answer }\end{array}$ & $\begin{array}{r}182 \\
174 \\
194 \\
63 \\
105 \\
273 \\
14\end{array}$ & $\begin{array}{r}9.9 \\
9.8 \\
29.4 \\
47.6 \\
38.1 \\
70.3 \\
57.1\end{array}$ \\
\hline Household Income & $\begin{array}{l}\text { Can you please indicate the group in which you } \\
\text { would place you and your partner/spouse's } \\
\text { current total gross income from all sources before } \\
\text { deductions, tax and national insurance }- \text { that is } \\
\text { income from work and any other sources, such as } \\
\text { pensions and benefits? } \\
1=\text { Under } £ 50 \text { per week } \\
2=£ 50 \text { - } £ 74 \text { per week } \\
3=£ 75-£ 99 \text { per week } \\
4=£ 100-£ 199 \text { per week } \\
5=£ 150-£ 199 \text { per week } \\
6=£ 200-£ 249 \text { per week } \\
7=£ 250-£ 299 \text { per week } \\
8=£ 300-£ 399 \text { per week } \\
9=£ 400-£ 499 \text { per week } \\
10=£ 500-£ 599 \text { per week } \\
11=£ 600\end{array}$ & $\begin{array}{r}10 \\
29 \\
43 \\
102 \\
118 \\
101 \\
92 \\
112 \\
98 \\
80 \\
220\end{array}$ & $\begin{array}{r}20.0 \\
37.9 \\
55.8 \\
64.7 \\
58.5 \\
56.4 \\
53.3 \\
35.7 \\
20.4 \\
15.0 \\
5.5\end{array}$ \\
\hline Working Status & $\begin{array}{l}\text { Working Status of Respondent } \\
1=\text { Full-time } \\
2=\text { Part-time } \\
3=\text { Retired } \\
4=\text { Student } \\
5=\text { Homemaker } \\
6=\text { Unemployed } \\
7=\text { Other } \\
8=\text { No answer }\end{array}$ & $\begin{array}{r}371 \\
118 \\
258 \\
102 \\
84 \\
46 \\
22 \\
4\end{array}$ & $\begin{array}{r}16.4 \\
20.3 \\
75.6 \\
4.9 \\
42.9 \\
54.3 \\
59.1 \\
75.0\end{array}$ \\
\hline Tenure & $\begin{array}{l}\text { Tenure } \\
1=\text { Owned } \\
2=\text { Social Housing (rent from council or housing }\end{array}$ & $\begin{array}{l}646 \\
147\end{array}$ & $\begin{array}{l}33.0 \\
63.9\end{array}$ \\
\hline
\end{tabular}




\begin{tabular}{|l|l|r|l|}
\hline & association) & \\
& 3=Rent from private landlord & 189 & 25.4 \\
& 4=Other & 19 & 31.6 \\
& 5=No answer & 4 & 25.0 \\
\hline
\end{tabular}




\begin{tabular}{|c|c|c|c|}
\hline $\begin{array}{l}\text { Young People in } \\
\text { Household }\end{array}$ & $\begin{array}{l}\text { Are there young people under } 18 \text { in the } \\
\text { household? } \\
1=\text { Young people under } 18 \\
0=\text { No young people under } 18\end{array}$ & $\begin{array}{l}400 \\
605\end{array}$ & $\begin{array}{l}24.8 \\
43.5\end{array}$ \\
\hline Disability & $\begin{array}{l}\text { Do you have any long term-illness, health } \\
\text { problem or disability which limits your daily } \\
\text { activities or the work you can do? } \\
1=\text { Yes } \\
0=\text { No }\end{array}$ & $\begin{array}{l}154 \\
851\end{array}$ & $\begin{array}{l}74.0 \\
29.1\end{array}$ \\
\hline $\begin{array}{l}\text { City Neighbourhood } \\
\text { Districts }\end{array}$ & $\begin{array}{l}\text { Postcode where respondent resides } \\
\text { PO1 }(1=\mathrm{P} 01 ; 0=\text { not PO1 }) \\
\text { PO2(1=P02; } 0=\text { not PO2) } \\
\text { PO3 }(1=\mathrm{P} 03 ; 0=\text { not PO3 }) \\
\text { PO4 }(1=\mathrm{P} 04 ; 0=\text { not PO4 }) \\
\text { PO5 }(1=\mathrm{P} 05 ; 0=\text { not PO5 }) \\
\text { PO6 }(1=\mathrm{P} 06 ; 0=\text { not PO6 })\end{array}$ & $\begin{array}{l}129 \\
173 \\
126 \\
250 \\
121 \\
188\end{array}$ & $\begin{array}{l}48.8 \\
32.9 \\
30.2 \\
29.6 \\
33.9 \\
44.7\end{array}$ \\
\hline
\end{tabular}


Table 2: Cross Tabulation of those who are digitally excluded in Portsmouth, England by each of the explanatory variables*

\begin{tabular}{|c|c|c|}
\hline Variables & $\begin{array}{l}\text { Number of } \\
\text { Respondents } \\
(\mathrm{N}=663)\end{array}$ & Digitally Excluded (\%) \\
\hline $\begin{array}{l}\text { Gender: } \\
1=\text { Male } \\
0=\text { Female }\end{array}$ & $\begin{array}{l}314 \\
349 \\
\end{array}$ & $\begin{array}{l}32.2 \\
37.5 \\
\end{array}$ \\
\hline 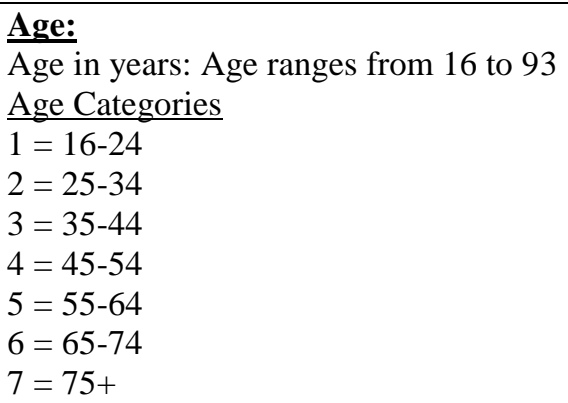 & $\begin{array}{r}88 \\
124 \\
156 \\
90 \\
76 \\
66 \\
63\end{array}$ & $\begin{array}{l}14.8 \\
18.5 \\
19.2 \\
21.1 \\
55.3 \\
78.8 \\
84.1\end{array}$ \\
\hline $\begin{array}{l}\text { Highest Educational Qualification: } \\
\text { 1= Degree or equivalent } \\
\text { 2= GCE A Level or equivalent } \\
3=\text { GCSE grades A, B, C or equivalent } \\
4=\text { GCSE grades D, E or equivalent } \\
5=\text { Other } \\
6=\text { None of the qualifications } \\
7=\text { No Answer }\end{array}$ & $\begin{array}{r}127 \\
114 \\
135 \\
39 \\
70 \\
173 \\
5\end{array}$ & $\begin{array}{r}8.7 \\
7.9 \\
29.6 \\
51.3 \\
35.7 \\
71.7 \\
60.0 \\
\end{array}$ \\
\hline $\begin{array}{l}\text { Household Income: } \\
1=\text { Under } £ 50 \text { per week } \\
2=£ 50-£ 74 \text { per week } \\
3=£ 75-£ 99 \text { per week } \\
4=£ 100-£ 149 \text { per week } \\
5=£ 150-£ 199 \text { per week } \\
6=£ 200-£ 249 \text { per week } \\
7=£ 250-£ 299 \text { per week } \\
8=£ 300-£ 399 \text { per week } \\
9=£ 400-£ 499 \text { per week } \\
10=£ 500-£ 599 \text { per week } \\
11=£ 600+\end{array}$ & $\begin{array}{r}10 \\
25 \\
36 \\
69 \\
64 \\
58 \\
55 \\
49 \\
50 \\
61 \\
186 \\
\end{array}$ & $\begin{array}{r}20.0 \\
44.0 \\
58.3 \\
76.8 \\
60.9 \\
60.3 \\
49.1 \\
28.6 \\
16.0 \\
18.0 \\
5.9 \\
\end{array}$ \\
\hline $\begin{array}{l}\text { Working Status } \\
1=\text { Full-time } \\
2=\text { Part-time } \\
3=\text { Retired } \\
4=\text { Student } \\
5=\text { Homemaker } \\
6=\text { Unemployed } \\
7=\text { Other } \\
8=\text { No Answer }\end{array}$ & $\begin{array}{r}270 \\
80 \\
155 \\
50 \\
57 \\
34 \\
16 \\
1 \\
\end{array}$ & $\begin{array}{r}14.8 \\
16.2 \\
80.6 \\
2.0 \\
42.1 \\
61.8 \\
43.8 \\
100.0\end{array}$ \\
\hline $\begin{array}{l}\text { Tenure } \\
1=\text { Owned } \\
2=\text { Social Housing } \\
3=\text { Private Landlord } \\
4=\text { Other } \\
5=\text { No Answer }\end{array}$ & $\begin{array}{r}419 \\
84 \\
140 \\
18 \\
2\end{array}$ & $\begin{array}{r}33.2 \\
59.5 \\
26.4 \\
33.0 \\
0.0\end{array}$ \\
\hline $\begin{array}{l}\text { Young People in Household: } \\
1=\text { Young People under } 18 \\
0=\text { No young people under } 18\end{array}$ & $\begin{array}{l}264 \\
399\end{array}$ & $\begin{array}{l}22.3 \\
43.4\end{array}$ \\
\hline
\end{tabular}




\begin{tabular}{|l|r|l|}
\hline Disability & 103 & 68.9 \\
$1=$ Yes & 560 & 28.8 \\
$0=$ No & & \\
\hline Postcode where respondent resides & 81 & 50.6 \\
PO1(1=P01; 0= not PO1) & 147 & 32.0 \\
PO2(1=P02; $0=$ not PO2) & 95 & 32.6 \\
PO3(1=P03; 0= not PO3) & 160 & 27.5 \\
PO4(1=P04; $0=$ not PO4) & 51 & 35.3 \\
PO5(1=P05; 0= not PO5) & 113 & 41.6 \\
PO6(1=P06; $0=$ not PO6) & & \\
\hline
\end{tabular}

*Definition of variables is the same as that outlined in Table 1 . 


\section{MODELLING APPROACH}

For the empirical phase two logistic regressions are performed to understand the socioeconomic determinants of those that are digitally excluded. The probability of being digitally included is estimated by the values given of the explanatory variables. These include gender, age, income, education, working status, tenure, city neighbourhood districts ('supergroups'), disability and the presence of young people in the household.

In the logistic regression model, the relationship between $\mathrm{Z}$ and the probability of the person being digitally included is linked to the function

$$
\begin{gathered}
\pi_{i}=\frac{e^{z i}}{1+e^{z i}}=\frac{1}{1+e^{-z i}} \\
\text { Or } \\
Z_{i}=\log \left(\frac{\pi_{i}}{i-\pi_{i}}\right)
\end{gathered}
$$

Where

$\pi_{i}=$ the probability of being digitally included.

$Z_{i}=$ the value of the unobserved continuous variable for the ith case.

It is also assumed by the model that $\mathrm{Z}$ is linearly related to the predictors.

$$
Z_{i}=\beta_{o}+\beta_{1} x_{i 1}+\beta_{2} x_{i 2}+\ldots . .+\beta_{p} x_{i p}
$$

Where

$X_{i j}$ is the $j_{t h}$ predictor for the $i_{t h}$ case

$B_{j}$ is the $j_{t h}$ coefficient

$p$ is the number of predictors

Since $\mathrm{Z}$ is unobserved, the predictors must relate to the probability of being digitally included by substituting for $Z$. An iterative maximum likelihood method is used to estimate the coefficients of the regression.

$$
\pi_{i}=\frac{1}{1+e^{-\left(\beta_{o}+\beta \mathrm{Xi} 1+\cdots+\beta \mathrm{pXip}\right)}}
$$




\section{RESULTS}

To understand the determinants of digital exclusion two logistic regressions are performed. Model 1 uses the income imputed variable and model 2 uses the data of the respondents who revealed their gross household income only. The findings are robust to all regressions. As expected the strength of the significance is improved as the imputed income variable provides more observations. The results from the logistic regressions are reported in Table 3. For each model the coefficient of each explanatory variable, their standard errors, the p-value the test of its significance as well as the odds $\operatorname{ratio} / \operatorname{Exp}(\beta)$ are presented. The pseudo R-square results of Cox \& Snell as well as Nagelkerke are calculated to assess the overall goodness of fit of the models and the overall rates of correct classification are also provided.

The $\mathrm{R}^{2}$ values for model 1 are between 0.423 and 0.580 while for model 2 are between 0.468 and 0.643 . These results indicate that the models contribute in explaining digital exclusion. Additionally, the Hosmer and Lemshow test indicates that the data fits both models well. Finally, the classification rate gives the overall percent of cases that are predicted correctly by the full model. The full model includes all independent variables. The overall rates of correct classifications are quite high at $82.7 \%$ for model 1 and $85.1 \%$ for model 2 .

\section{Model 1: The determinants of digital exclusion using the income imputed variable}

Model 1 identifies the characteristics of those that are digitally excluded. The statistically significant determinants of digital exclusion for model 1 include age, income, education level, working status, the presence of young people in the household and disability as well as city neighbourhood districts PO1, P04 and PO6.

With regards to age the results indicate that as people get older they are less likely to be digitally included.

As expected income is an important determinant of being digitally excluded. The overall effect of the imputed income variable is statistically significant. The results show that those that don't earn $£ 600$ per week are less likely to be digitally included. The odds ratio for income category ( $£ 500-£ 599$ per week) is .405 indicating that those who fall into this income category are less likely to be digitally included than those who earn $£ 600+$ per week. The odds ratio for each of the other income categories decreases substantially highlighting that those who fall into the lower income categories are less likely to be digitally included. The income category ( $<£ 50$ per week) is statistically insignificant. However, this may relate to students who are working while studying.

Education also plays an important role in determining who is digitally included or not. The odds ratio for GCSE grades A, B, C or equivalent is .295, for GCSE grades D, E or equivalent is .144 and for none of the formal qualifications listed is .206. This shows that those who have lower levels of education are less likely to be digitally included than those who have a degree or equivalent.

The working status of the respondent also plays a role in determining digital exclusion. Within this variable students are statistically significant indicating that they are 8.773 times more likely to be digitally included than those who work full-time. 
The presence of young people in the household is also statistically significant. The odds ratio indicates that households that have young people under 18 are 1.877 times more likely to be digitally included than those who do not.

Disability also affects the probability of being digitally included. The odds ratio of .481 means that those who do have a disability are .481 less likely to be digitally included than those who do not have a disability.

With regards to the city neighbourhood districts, PO3 is used as the reference category because it is described in an earlier section of the paper as having typical traits. The results show that PO1, PO4 and PO6 are statistically significant indicating that residents residing in these districts are less likely to be digitally included than residents residing in PO3. This is expected for postcode PO1 and PO6 as the largest supergroup in PO1 is constrained by circumstances. Residents in these areas are more likely to live in flats and rent from the council and housing association rather than live in detached housing. Households are less likely to have access to two or more cars and residents are less likely to hold higher education qualifications. With regards to PO6 this is described as been a very mixed area as it includes some prospering suburbs but it does include some of the most deprived areas as well as some blue collar communities. PO4 is statistically significant at the $10 \%$ level. Again, this is not surprising as typical traits dominate PO4.

\section{Model 2: The determinants of digital exclusion using those who revealed their gross household income only}

Model 2 identifies the characteristics of those that are digitally excluded using only the respondents who revealed their gross household income

Age is statistically significant at the $10 \%$ level indicating that as people get older they are less likely to be digitally included.

As expected income influences whether or not one is digitally included. The reference group are those whose gross household income is $£ 600+$ per week. Overall income is statistically significant. All income categories within are statistically significant except income category $(<£ 50$ per week) and ( $£ 400-£ 499$ per week). As before, the odds ratio for each of the other income categories decreases substantially highlighting that those who fall into the lower income categories are less likely to be digitally included.

Education plays an important role in determining who is digitally excluded. The odds ratio for GCSE grades A, B, C or equivalent, GCSE grades D, E or equivalent and have none of the formal qualifications listed reinforces the previous results that those whose qualifications are lower than those who have a degree or equivalent have lower probabilities of being digitally included.

The working status of the respondent plays a role in determining digital exclusion. Within this variable, students they are 27.974 times more likely to be digitally included than those who work full-time. Those who are retired are also statistically significant indicating that they are .345 times less likely to be digitally included than those who work full-time.

The presence of young people in the household is marginally statistically significant at the $10 \%$ level. The odds ratio reinforces the previous results that households that have young people present are more likely to be digitally included than those who do not. 
With regards to the city neighbourhood districts PO1 and PO6 are both statistically significant at the $10 \%$ level indicating as before that respondents residing in these districts are less likely to be digitally included than respondents residing in PO3. 
Table 3: Logistic Regression Results to understand the determinants of those digitally excluded in Portsmouth, England.

\begin{tabular}{|c|c|c|c|c|c|c|c|c|}
\hline \multirow[b]{2}{*}{ Variables } & \multicolumn{4}{|c|}{$\begin{array}{l}\text { Model } 1^{1} \text { : Digitally Included } \\
\text { using the imputed income } \\
\text { variable }\end{array}$} & \multicolumn{4}{|c|}{$\begin{array}{l}\text { Model } 2^{1} \text { : Digitally Included using } \\
\text { only respondents who revealed their } \\
\text { gross household income }\end{array}$} \\
\hline & $\beta$ & S.E. & p-value & $\operatorname{Exp}(\beta)$ & $\beta$ & S.E. & p-value & $\operatorname{Exp}(\beta)$ \\
\hline Gender(males) $^{2}$ & -0.040 & 0.216 & 0.855 & 0.961 & -0.163 & 0.309 & 0.599 & 0.850 \\
\hline Age in years & -0.031 & 0.010 & 0.002 & 0.970 & -0.024 & 0.014 & 0.090 & 0.976 \\
\hline Income $^{3}$ & & & 0.000 & & & & 0.000 & \\
\hline$<£ 50$ per week & -1.276 & \begin{tabular}{|l|}
1.117 \\
\end{tabular} & 0.253 & 0.279 & -1.060 & 1.262 & 0.401 & 0.347 \\
\hline$£ 50-£ 74$ per week & -3.047 & 0.740 & 0.000 & 0.048 & -3.575 & 0.847 & 0.000 & 0.028 \\
\hline$£ 75-£ 99$ per week & -3.642 & 0.711 & 0.000 & 0.026 & -3.192 & 0.786 & 0.000 & 0.041 \\
\hline$£ 100-£ 149$ per week & -2.779 & 0.519 & 0.000 & 0.062 & -2.674 & 0.582 & 0.000 & 0.069 \\
\hline$£ 150-£ 199$ per week & -2.327 & 0.482 & 0.000 & 0.098 & -2.847 & 0.582 & 0.000 & 0.058 \\
\hline$£ 200-£ 249$ per week & -2.281 & 0.453 & 0.000 & 0.102 & \begin{tabular}{|l|}
-2.372 \\
\end{tabular} & 0.537 & 0.000 & 0.093 \\
\hline$£ 250-£ 299$ per week & -1.873 & 0.428 & 0.000 & 0.154 & -1.701 & 0.490 & 0.001 & 0.183 \\
\hline$£ 300-£ 399$ per week & -1.767 & 0.405 & 0.000 & 0.171 & -1.577 & 0.530 & 0.003 & 0.207 \\
\hline$£ 400-£ 499$ per week & -1.072 & 0.433 & 0.013 & 0.342 & -0.181 & 0.608 & 0.766 & 0.835 \\
\hline$£ 500-£ 599$ per week & -0.903 & 0.476 & 0.058 & 0.405 & -1.012 & 0.534 & 0.058 & 0.363 \\
\hline Education Level $^{4}$ & & & 0.000 & & & & 0.000 & \\
\hline GCE (A level or equivalent) & -0.280 & 0.433 & 0.517 & 0.756 & -0.611 & 0.608 & 0.315 & 0.543 \\
\hline GCSE grades $\mathrm{A} / \mathrm{B} / \mathrm{C}$ or equivalent & -1.220 & 0.369 & 0.001 & 0.295 & -1.648 & 0.504 & 0.001 & 0.192 \\
\hline GCSE grades D/E or equivalent & -1.936 & 0.455 & 0.000 & 0.144 & -2.175 & 0.610 & 0.000 & 0.114 \\
\hline Other & -1.164 & 0.401 & 0.004 & 0.312 & -1.522 & 0.545 & 0.005 & 0.218 \\
\hline None of the qualifications & -1.580 & 0.367 & 0.000 & 0.206 & -2.125 & 0.499 & 0.000 & 0.119 \\
\hline No answer & -1.025 & 0.755 & 0.175 & 0.359 & -2.555 & 1.462 & 0.081 & 0.078 \\
\hline Working Status $^{5}$ & & & 0.002 & & & & 0.001 & \\
\hline Part-time & 0.152 & 0.343 & 0.658 & 1.164 & 0.239 & 0.460 & 0.604 & 1.269 \\
\hline Retired & -0.455 & 0.373 & 0.222 & 0.634 & -1.063 & 0.513 & 0.038 & 0.345 \\
\hline Student & 2.172 & 0.630 & 0.001 & 8.773 & 3.218 & 1.171 & 0.006 & 24.974 \\
\hline Homemaker & -0.536 & 0.376 & 0.154 & 0.585 & -0.435 & 0.504 & 0.388 & 0.647 \\
\hline Unemployed & -0.408 & 0.460 & 0.375 & 0.665 & -0.468 & 0.590 & 0.428 & 0.626 \\
\hline Other & 0.481 & 0.605 & 0.426 & 1.618 & 1.423 & 0.756 & 0.060 & 4.148 \\
\hline No Answer** & -0.407 & 1.780 & 0.819 & 0.665 & & & & \\
\hline Tenure $^{6}$ & & & 0.198 & & & & 0.258 & \\
\hline Social Housing & -0.387 & 0.311 & 0.213 & 0.679 & -0.030 & 0.408 & 0.940 & 0.970 \\
\hline Private Landlord & -0.358 & 0.330 & 0.278 & 0.699 & -0.316 & 0.433 & 0.465 & 0.729 \\
\hline Other & -1.004 & 0.659 & 0.128 & 0.366 & -1.418 & 0.738 & 0.054 & 0.242 \\
\hline No Answer** & 2.067 & 1.358 & 0.128 & 7.902 & & & & \\
\hline$*$ YPH $(\text { young people }<18)^{7}$ & 0.630 & 0.235 & 0.007 & 1.877 & 0.556 & 0.328 & 0.090 & 1.743 \\
\hline Disability(yes) ${ }^{8}$ & -0.732 & 0.287 & 0.011 & 0.481 & -0.633 & 0.406 & 0.119 & 0.531 \\
\hline \multicolumn{9}{|l|}{ City Neighbourhood Districts - Postcode ${ }^{9}$} \\
\hline PO1 & -0.777 & 0.376 & 0.039 & 0.460 & -0.875 & 0.474 & 0.065 & 0.417 \\
\hline $\mathrm{PO} 2$ & -0.522 & 0.349 & 0.135 & 0.593 & -0.326 & 0.423 & 0.442 & 0.722 \\
\hline PO4 & -0.616 & 0.332 & 0.064 & 0.540 & -0.344 & 0.438 & 0.433 & 0.709 \\
\hline PO5 & -0.509 & 0.407 & 0.211 & 0.601 & -0.242 & 0.723 & 0.738 & 0.785 \\
\hline PO6 & -1.044 & 0.340 & 0.002 & 0.352 & -0.733 & 0.434 & 0.091 & 0.481 \\
\hline Constant & 5.542 & 0.724 & 0.000 & 255.239 & 5.477 & 0.963 & 0.000 & 239.200 \\
\hline $\mathrm{N}$ & 987 & & & & 644 & & & \\
\hline $\mathrm{R}^{2}$ Cox-Snell & 0.423 & & & & 0.468 & & & \\
\hline $\mathrm{R}^{2}$ Nagelkerke & 0.580 & & & & 0.643 & & & \\
\hline $\begin{array}{l}\text { Hosmer and Lemeshow Statistic } \\
\text { P value }\end{array}$ & $\begin{array}{l}4.919 \\
0.766 \\
\end{array}$ & & & & $\begin{array}{l}1.755 \\
0.988 \\
\end{array}$ & & & \\
\hline Classification (\%) & 82.7 & & & & \begin{tabular}{|l|}
85.1 \\
\end{tabular} & & & \\
\hline \multicolumn{9}{|c|}{$\begin{array}{l}\text { *YPH - Young People in Household. } * * \text { In model } 2 \text { respondents who did not answer the question related to tenure and } \\
\text { working status have been excluded from the analysis because after excluding those who did not reveal their income reduced } \\
\text { the size of these categories. } \\
\text { IDependent variable }(1=\text { digitally included; } 0=\text { not digitally included) } \\
\text { Reference Categories used in the model: }{ }^{2} \text { females, }{ }^{3} \text { income group } £ 600+\text { per week, }{ }^{4} \text { degree or equivalent, }{ }^{5} \text { full-time, }{ }^{6} \text { own } \\
\text { their home, }{ }^{7} \text { no young people under } 18,{ }^{8} \text { those who do not have a disability, }{ }^{9} \text { those who reside in postcode PO3. } \\
\text { Respondents who did not answer which postcode district they reside in have been excluded from the analysis. This accounts } \\
\text { for } 1.8 \% \text { of respondents in model } 1 \text { and for } 1.6 \% \text { respondents in model } 2 .\end{array}$} \\
\hline
\end{tabular}




\section{CONCLUDING REMARKS}

This paper has contributed to existing literature on social and digital exclusion by providing an in-depth exploration of the attributes of those that are digitally excluded within one major English city, Portsmouth, England. Two logistic regression models were estimated to understand the determinants of digital exclusion. The findings are robust to all models. A statistically significant relationship is found between the explanatory variables and digital exclusion. As previous studies some of these include those in lower income categories, the elderly and those who have lower levels of education are less likely to be digitally included (Warf 2012, Vicente and Lopez, 2006; Dutton et al, 2007; Bucy, 2000). The results also show that students are more likely to be digitally included. Previous research found similar results. Additionally, this study also reports that those with a disability are less likely to be digitally included and households with young people were more likely to be digitally included. This complements previous work by Dutton et al (2009).

Other studies focused across countries or included the country of residence to help unravel the digital divide and found a difference (Ono and Zavodny, 2007; Vicente and Lopez, 2006). This study also focused on the spatial differences of digital exclusion by including in the model the postcodes of where respondents reside. The postcode district is used instead of the full postcodes to avoid breaching anonymity. The postcode PO3 is used as the reference category as it is best described as having typical traits. This study shows that spatial differences exists as respondents who reside in other postcode areas that are constrained by circumstances or are very mixed are less likely to be digitally included. Previous studies also investigated if any gender difference exists in using the internet. In the US the gender gap seemed to have disappeared by 2000 (Ono and Zavodny, 2003) but others found that a gender gap exists in both access and use of the internet (Bimber, 2000). In the UK Dutton et al (2009) suggests that a gender gap exists but it has been decreasing overtime. In this study gender was included in the analysis and was found to be insignificant.

There are important policy implications arising out of this. The study identifies groups for whom the government can help to reduce the 'digital gap' that exists. This is important as in recent years society has seen a huge change in how information is communicated. Accessing information via the internet has become a common activity in the everyday life for many people around the world. However, there are many people who do not reap the benefits from such activity.

It is useful to note that those who are more likely to be digitally excluded are the elderly, the poor, those with a disability, and those without Universities degrees. These attributes are traditionally associated with other forms of social exclusion. Digital exclusion is a modern element that can compound disadvantage. This link between social exclusion and digital exclusion highlights to policy makers that digital exclusion cannot be solved separately from other policy areas. Additionally, this study shows that households with no young children are less likely to be digitally included or engaged. This appears potentially counter-intuitive. It may be accounted for by young people serving as early adopters to technology and bringing technology into the home. Arguably over time, this will reduce as older people also adopt such technology. 
Figure 1: Location of the city of Portsmouth, Hampshire, England

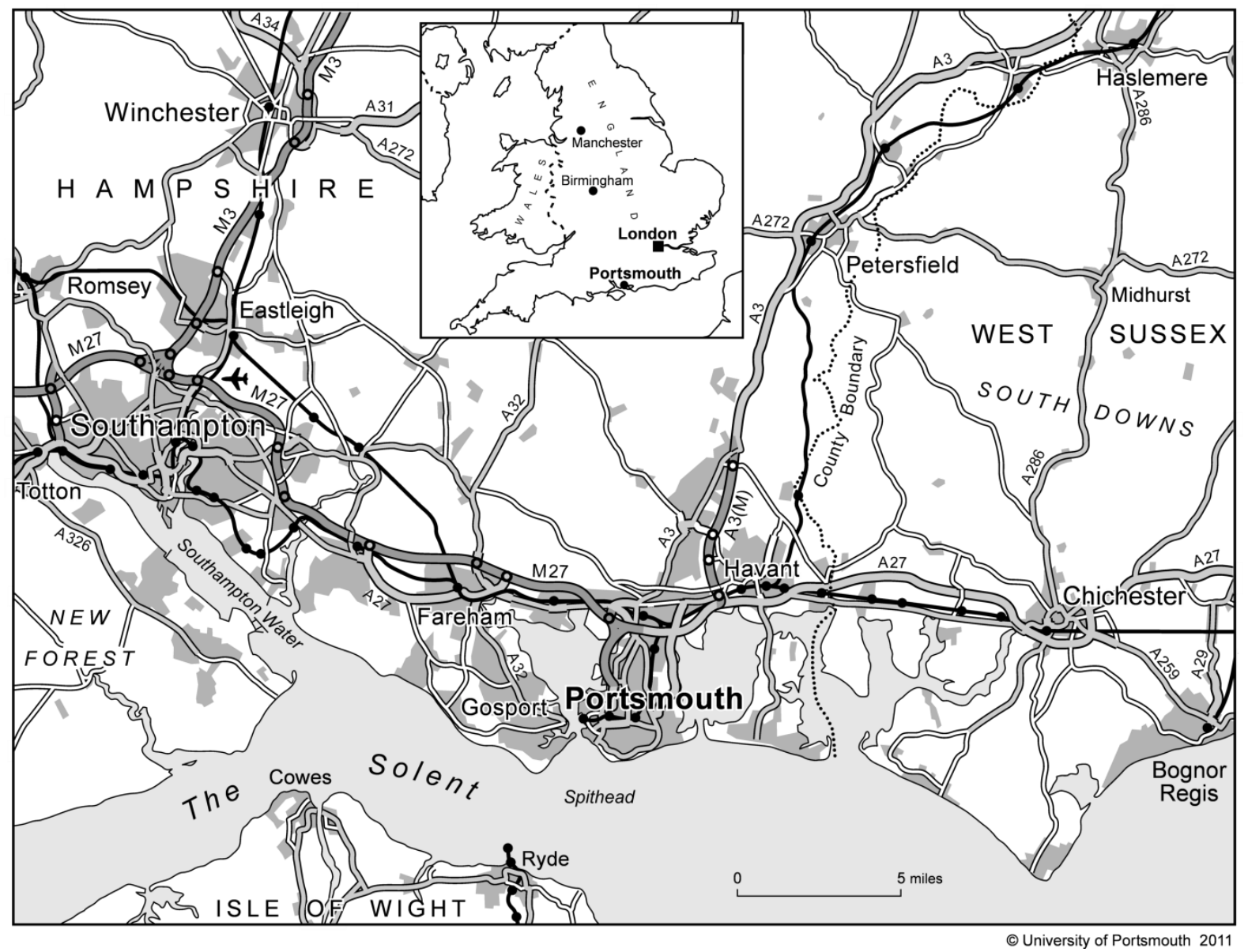


Figure 2: Percentage of respondents that are digitally excluded by each of the postcodes in Portsmouth, Hampshire, England

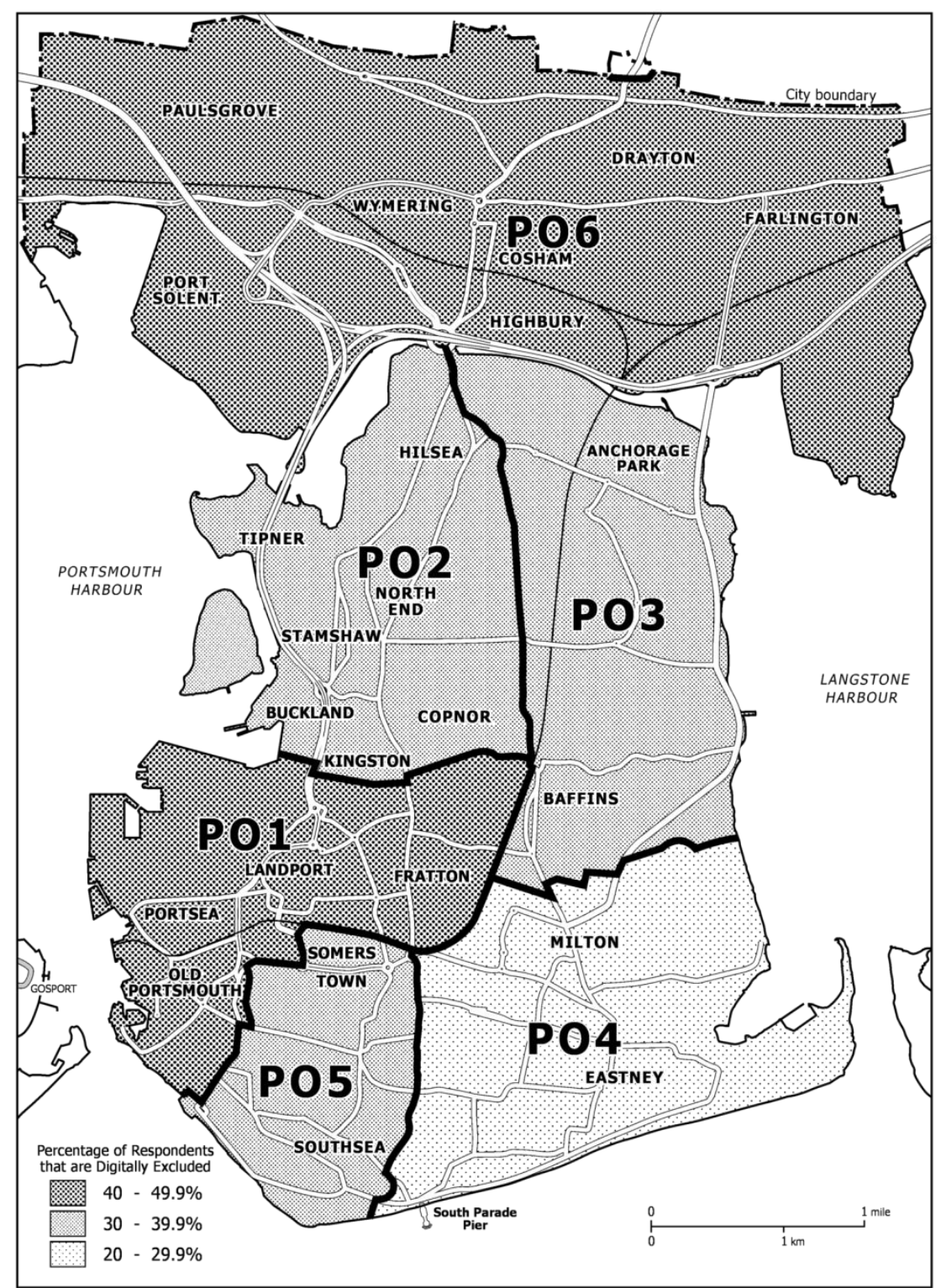


Figure 3: Portsmouth and UK; Population Proportion by Super Group

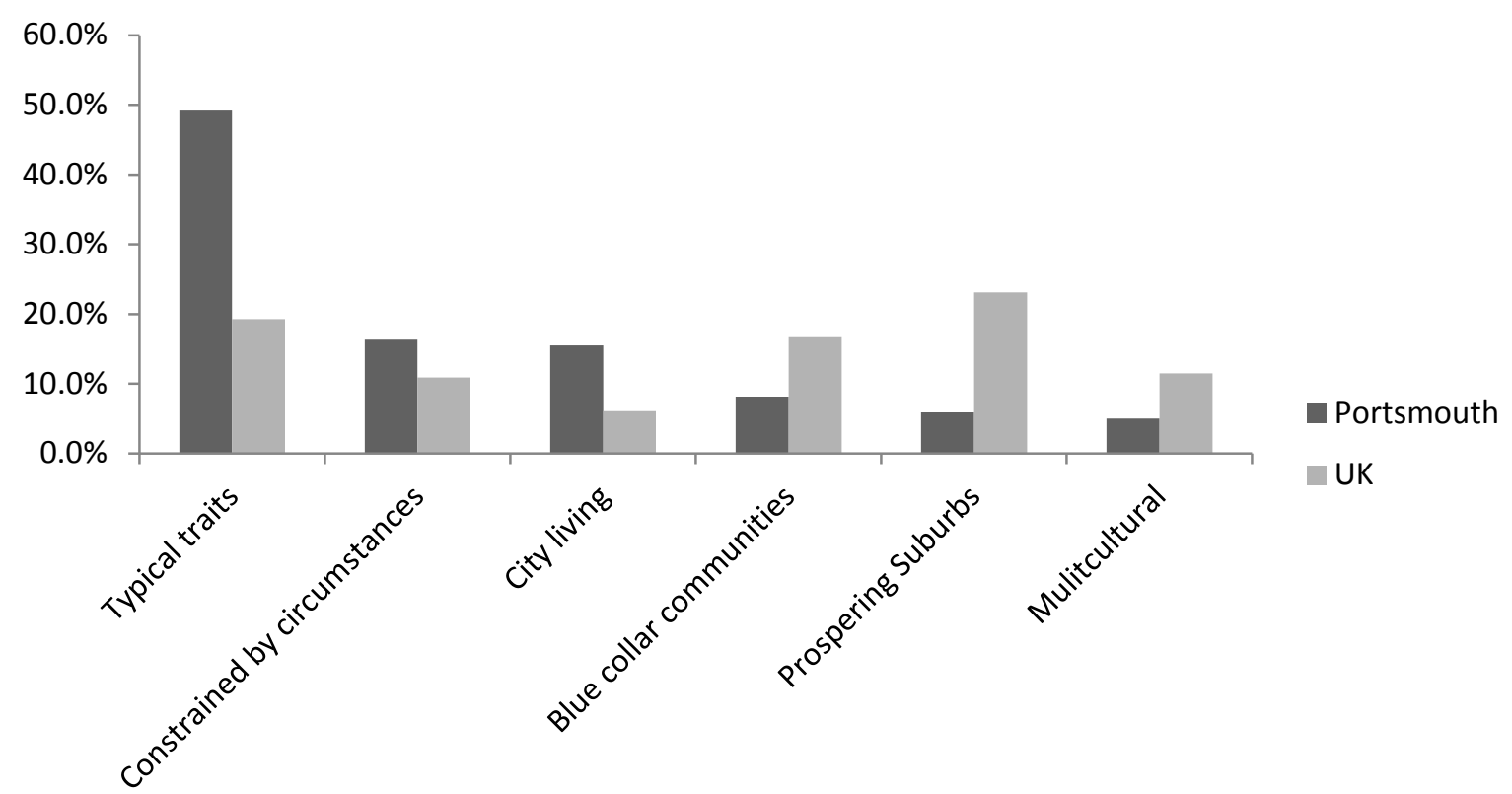

Super Group

Source: Portsmouth City Council (2010), Portsmouth Population Profile: A profile of Portsmouth's population using Output Area Classification

Figure 4: Percentage of Respondents Digitally Excluded by Age Group

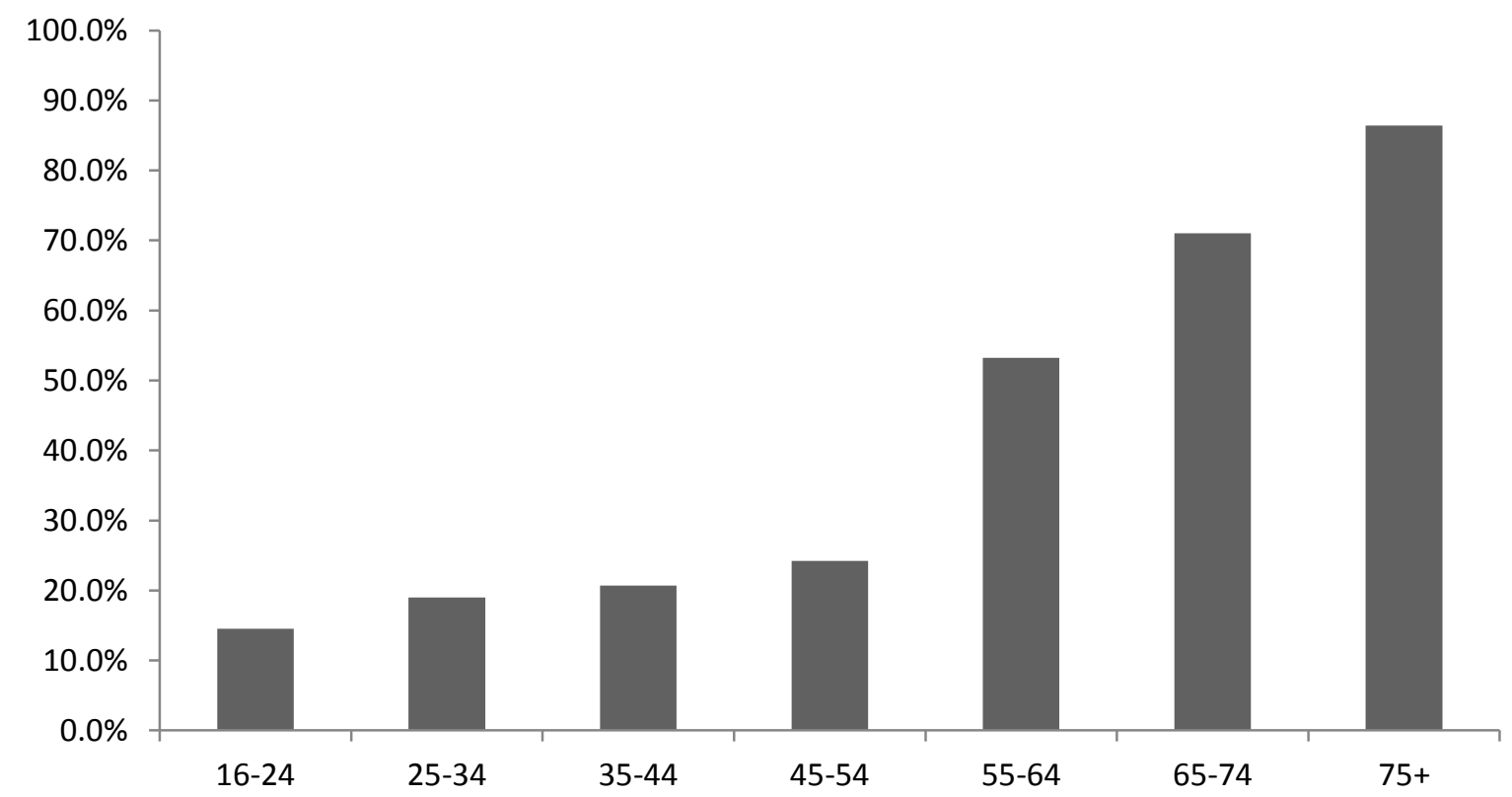

Age Group 
Figure 5: Percentage of Respondents Digitally Excluded by Education Level

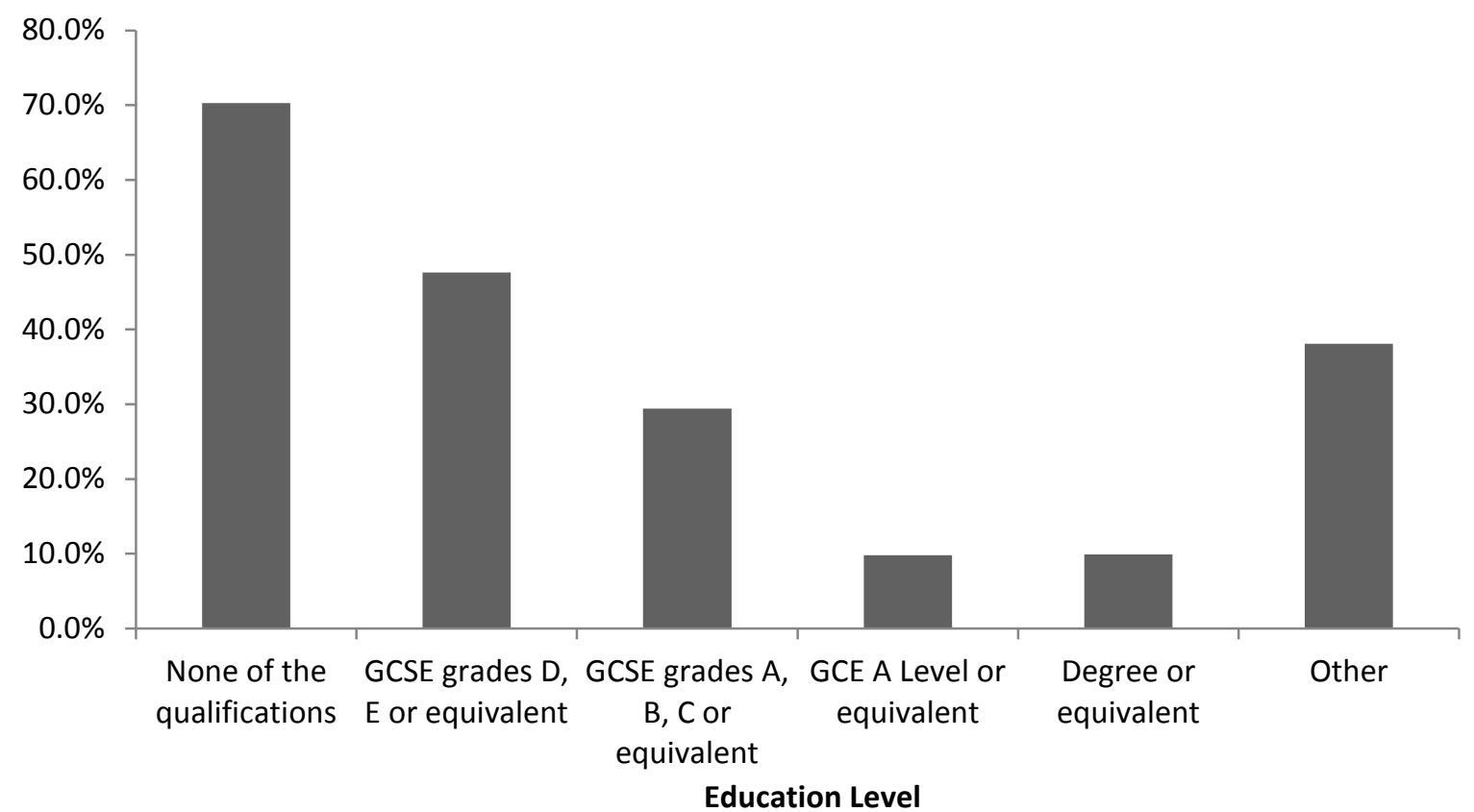

Figure 6: Percentage of Respondents Digitally Excluded by Income

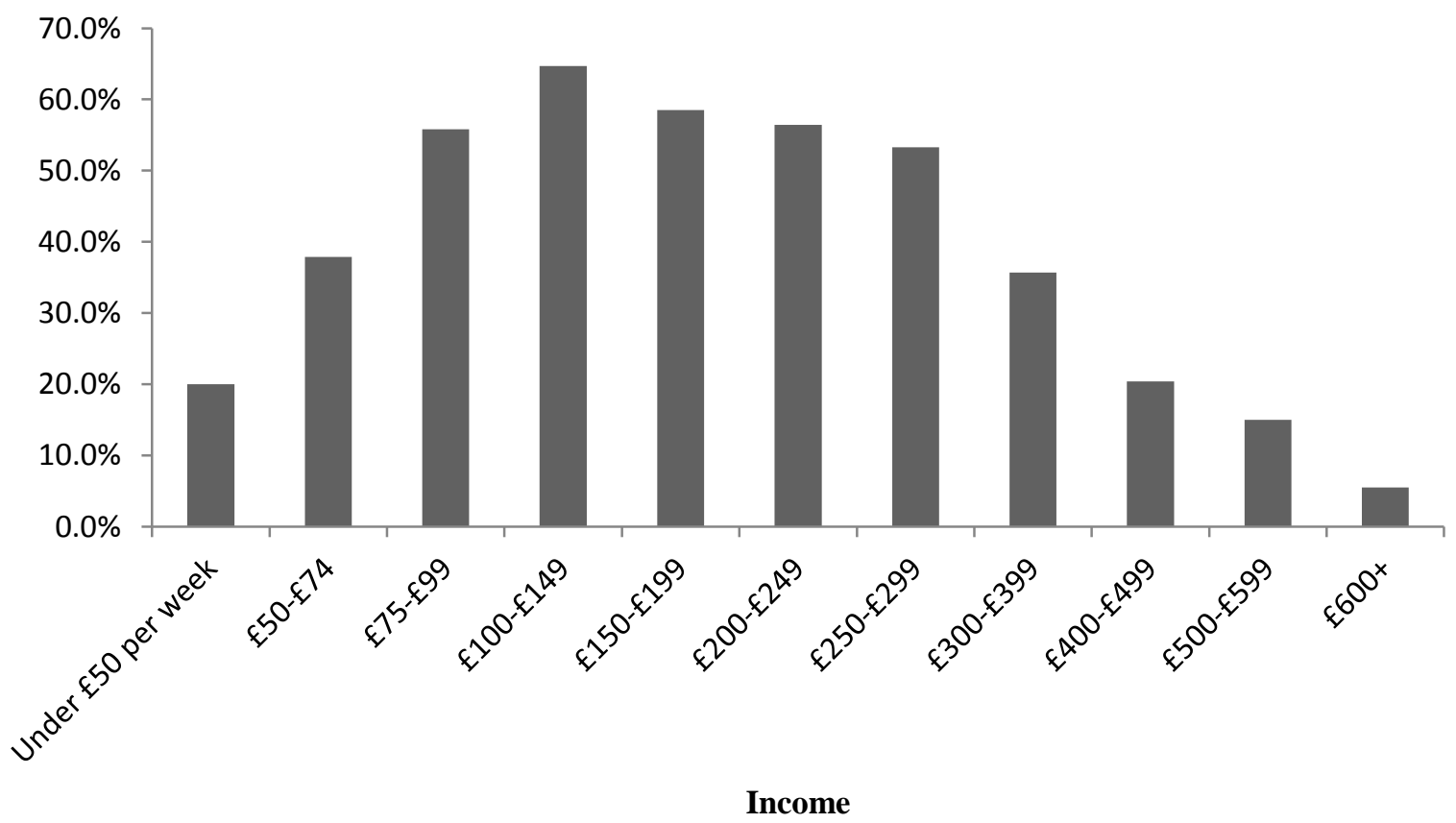




\section{REFERENCES}

BIMBER, B. (2000), Measuring the Gender Gap on the Internet. Social Science Quarterly, 81, pp. 868-876.

BUCY, E. P. (2000), Social Access to the Internet. The International Journal of Press Politics, 5, pp. 50-61.

DUTTON, W.H., E.J. HELSPER \& M.M. GERBER, (2009), The Internet in Britain: 2009. Oxford Internet Institute, University of Oxford.

DUTTON, W. \& E.J. HELSPER (2007), The Internet in Britain: 2007. Oxford Internet Institute, University of Oxford (Oxford, UK).

FAIRLIE, R. W. (2004), Race and the Digital Divide. Contributions to Economic Analysis \& Policy, 3, pp. 1-38.

FRESHMINDS (2008), Understanding Digital Exclusion Research Report. Available at: www.communities.gov.uk/documents/communities/doc/1066166.doc. Accessed on 1 October 2011.

FOLEY, P. (2004), Does the Internet help to overcome social exclusion? Electronic Journal of E-Government, 2, pp. 139-146.

HARGITTAI, E. (2003), The Digital Divide and What to Do about it, The New Economy Handbook, pp.821-831, edited by D.C. Jones. San Diego, Calif: Academic Press.

JACKSON, L.A., G. BARBATSIS, A. VON EYE, F.BIOCCA, Y. ZHAO, \& H.FITZGERALD (2003), Internet use in low-income families: implications for the digital divide, IT \& Society 1, pp. 141-165.

LIVINGSTONE, S., E. HELSPER (2007), Gradations in digital inclusion: Children, young people, and the digital divide, New Media and Society, 9, pp.671-696.

LONGLEY, P. A., A.D. SINGLETON, (2009), Linking social deprivation and digital exclusion in England, Urban Studies 46, pp. 1275-1298.

MCKENNA, K. Y. A. \& J.A. BARGH (2000), Plan 9 from cyberspace: the implications of the Internet for personality and social psychology, Personality and Social Psychology Review, 4, pp. 57-75.

NORRIS, P. (2001), Digital Divide: Civic Engagement, Information Poverty, and the Internet Worldwide. Cambridge: Cambridge University Press.

OECD (2001), Understanding the Digital Divide. Paris: OECD. Available at: http://www.oecd.org/dataoecd/38/57/1888451.pdf. Accessed on 1 October 2011.

ONO, H., M. ZAVODNY (2003), Gender and the Internet, Social Science Quarterly, 84, pp. 111-121. 
ONO, H., M. ZAVODNY (2007), Digital Inequality: A Five Country Comparison Using Microdata, Social Science Research, 36, pp. 1135-1155.

OFFICE FOR NATIONAL STATISTICS (2012), Internet Access - Households and Individuals, 2012.

OFFICE FOR NATIONAL STATISTICS (2009), Internet Access - Households and Individuals, 2009.

PARAYIL, G. (2005), The Digital Divide and Increasing Returns: Contradictions of Informational Capitalism, The Information Society, 21, pp. 41-51.

PORTSMOUTH CITY COUNCIL (2012a), The Portsmouth Plan: Portsmouth Core Strategy.

PORTSMOUTH CITY COUNCIL (2012b), Joint Strategic Needs Assessment: Summary for Commissioners 2012.

PORTSMOUTH CITY COUNCIL (2010), Portsmouth Population Profile.

PORTSMOUTH LOCAL STRATEGIC PARTNERSHIP(2011), Joint Strategic Needs Assessment Briefing Note Portsmouth City: social marketing strategies.

RUBIN, D.B. (1977), Formalizing Subjective Notions about the Effect of Nonrespondents in Sample Surveys, Journal of the American Statistical Association, 72, pp. 538-543.

TABACHNICK, B.G. \& L.S. FIDELL (2007), Using Multivariate Statistics. 5th edition. Boston: Pearson Education.

VICENTE, M.R. \& A.J. LOPEZ (2006), Patterns of ICT diffusion across the European Union, Economic Letters, 93, pp. 45-51.

WARF, B. (2012), Contemporary Digital Divides in the United States, Tijdschrift voor Economische en Sociale Geografie, 103, pp. 1-15.

WARSCHAUER, M. (2004), Technology and Social Inclusion: Rethinking the Digital Divide. Cambridge, MA: MIT Press.

WINCHESTER, N. (2009), Social housing and digital exclusion. National Housing Federation, London.

\footnotetext{
${ }^{\text {i }}$ Portsmouth City Council (2010), Portsmouth Population Profile: A profile of Portsmouth's population using Output Area Classification. This can be accessed online http://www.portsmouth.gov.uk/yourcouncil/18672.html ${ }^{i i}$ Rubin (1977) proposes using the method of multiple imputations to calculate missing observations. "This method produces a subjective probability interval for the statistic that would have been calculated if all non respondents had responded. Background information which is recorded for both respondents and non respondents plays an important role in sharpening the subjective interval...The general idea can be applied to any problem with non respondents or missing data" (Rubin 1977, p.538). This method is considered the most respectable method to deal with missing data (Tabachnick and Fidell 2007).
} 